\title{
iBOOKS STANDARDISATION AND GOOD PRACTICE FOR EFFECTIVE EDUCATION METHODS INSUPPORT OF ILEARNING
}

\author{
Untung Rahardja ${ }^{1}$ \\ Dewi Immaniar Desrianti ${ }^{2}$ \\ Siti Mawadah ${ }^{3}$ \\ e-mail : untung.rahardja@faculty.raharja.ac.id,dewiimmaniar@pribadiraharja.com, \\ sitimawadah@si.raharja.ac.id
}

Diterima : 5 Juli 2011/ Disetujui : 11 Agustus 2011

\begin{abstract}
Quality of education in indonesia currently recognized are still far from expected, which still need to be supported by systems that can dramatically improve the quality of education. Education also plays an important role in national development. Through the quality of a good education, will produce human become capable of competing in the era of globalization which is characterized by high competition. iLearning System or in integrated learning system is introduced in response to improve the quality of education. iLearning-based learning, requires a content to supportthe learning, one of which is the iBooks. However, current conditions, the iBooks are still not perfect in meeting the requirements of learning standards in iLearning. By making the standardization of raw and added components, the iBooks allows iLearning system to enter education in the value-weighted and uniform quality. In other words, iBooks standardization is a modern educational methods in iLearning system that characterize high-quality international competitiveness in education. This article identifies the problems encountered in education, especially in iLearning. This article also introduce a brief definition, the definition of iBooks, architecturaldesign of iLearning using iBooks, ten Literature Review that discusses the same issues as well as 20 items which must be contained within the standardization of raw iBooks in order to meet the learning element of iLearning. In its implementation, listing program written using HTML is demonstrated. Also 20 components that became the nucleus of an iBooks translated into their respective functions. Six advantages and three disadvantages of the new system is also discussed.
\end{abstract}

1. Dosen Jurusan Sistem Informasi, STMIK Raharja

J1. Jend Sudirman No. 40 Modern Cikokol-Tangerang Telp. 5529692

2. Dosen Jurusan Teknik Informatika, STMIK Raharja

J1. Jend Sudirman No. 40 Modern Cikokol-Tangerang Telp. 5529692

3. Mahasiswa Jurusan Sistem Informasi, STMIK Raharja

Jl. Jend Sudirman No. 40 Modern Cikokol-Tangerang Telp. 5529692 
Finally, contribution to the implementation of standardization of the deployment of iBooks is a solution that is very helpful in improving the quality of learning activities based iLearning in Higher Education towards the international standard of quality.

Key words: iLearning, iBooks, Standardization

\section{ABSTRAKSI}

Mutu pendidikan di negara kita saat ini diakui masih jauh dari yang diharapkan, dimana masih perlu di dukung oleh beberapa sistem yang dapat meningkatkan mutu pendidikan.Pendidikan memegang peran penting dalam pembangunan nasional. Melalui mutu pendidikan yang baik, akan terlahir manusia yang mampu bersaing di era globalisasi bercirikan high competition. Sistem iLearning (integrated Learning) atau dalam bahasa indonesia disebut sistem pembelajaran terpadu yang diterapkan merupakan salah satu bentuk untuk meningkatkan mutu menuju suatu pendidikan yang modern dan berkualitas. Pembelajaran berbasis iLearning, membutuhkan suatu content sebagai pendukung pendidikan yang salah satunya adalah iBooks. Namun kondisi pada saat ini, iBooks yang ada masih belum sempurna dalam memenuhi standarisasi pembelajaran iLearning.Dengan membuat standarisasi yang baku dan menambahkan beberapa komponen-komponen di dalam sebuah iBooks memungkinkan sebuah pembelajaran iLearning menjadi pendidikan berbobot dan seragam dalam nilai kualitas. Dengan kata lain standarisasi iBooks merupakan metode pendidikan modern dalam pembelajaran iLearning yang bermutu internasional dan mencirikan high competition. Dalam artikel ini di identifikasikan masalah yang dihadapi dalam suatu pendidikan khususnya dalam pembelajaran iLearning, definisi iLearning secara singkat, definisi iBooks tersebut, arsitekturiBooks dalam sebuah sistem iLearning, 10 Litelature Review yang membahas permasalahan yang sama serta 20 komponen yang harus terdapat didalam standarisasi baku sebuah iBooks agar dapat memenuhi unsur pembelajaran iLearning.Pada implementasinya, ditampilkan listing program yang ditulis menggunakanHTML. 20 komponen yang menjadi hal inti dalam sebuah iBooksdijabarkan kedalam fungsinya masing-masing. Dengan menambahkan 20 komponen tersebut ada 6 kelebihan dan 3 kekurangan didalamnya.Kontribusi penerapan standarisasi pembuatan iBooksmerupakan suatu solusi yang sangat membantu dalam meningkatkan kualitas kegiatan pembelajaran berbasis iLearning pada Perguruan Tinggi menuju mutu berstandar internasioal.

Kata kunci: iLearning, iBooks, Standarisasi

\section{PENDAHULUAN}

Kualitas dan mutu pendidikan perlu didukung oleh suatu sistem yang dapat meningkatkan mutu pendidikan. Peningkatan mutu pendidikan diperoleh melalui dua strategi, yaitu peningkatan mutu pendidikan yang berorientasikan akademis, untuk memberi dasar minimal dalam perjalanan harus ditempuh mencapai mutu pendidikan 
yang dipersyaratkan oleh tuntutan zaman dan peningkatan mutu yang berorientasi pada keterampilan hidup yang mencakup pendidikan yang berlandaskan luas, nyata dan bermakna. Maimunah et al (2010).

Metode pembelajaran saat ini semakin berkembang, mengikuti kemajuan teknologi yang semakin pesat. Sebuah metode pembelajaran sangat menentukan hasil atau output yang tercipta dari metode pembelajaran tersebut. Sumber daya manusia yang semakin hari di tuntut untuk lebih kreatif dan maju.Tentu saja semua itu dibutuhkan fasilitas yang memadai, oleh karena itu terciptalah sebuah metode pembelajaran yang bernama iLearning. Definisi iLearning adalah mengintegrasikan sumber daya dalam menjalankan Tridarma Perguruan Tinggi dengan menggunakan iPad menurut Untung Rahardja (2011).

Dalam dunia pendidikan, khususnya dibidang IT.Untuk melengkapi kebutuhan dasar IT dari sebuah metode pembelajaran, terciptalah iLearning. Para mahasiswa berlomba-lomba mengembangkan pola pikir mereka untuk bersaing menjadi yang paling depan menggunakan iLearning. Dengan di temukannya metode pembelajaran yang baru yaitu iLearning, maka dibutuhkan aplikasi-aplikasi yang menunjang metode pembelajaran tersebut untuk penyelarasan metode iLearning tersebut.Ada beberapa aplikasi yang menjadi hal utama dalam metode iLearning ini, salah satu di antaranya adalah iBooks. iBooks adalah sebuah aplikasi di dalam iPad yang berbentuk seperti rak buku dimana rak tersebut dapat memuat ratusan buku-buku. Aplikasi tersebut tentunya sangatlah membantu dan menopang metode iLearning ini.User dapat dengan mudah mengunduh buku yang diinginkan, ada beberapa pilihan buku, ada yang free dan tentu saja ada yang berbayar.

Adanya inovasi dari pendidikan, akhirnya terciptalah iBooksuntuk materimateri mata kuliah yang digunakan sebagai bahan ajar pembelajaran berbasis iLearning di dalam kelas. iBooks adalah salah satu aplikasi yang mendukung iLearning, definisi dari iBooks sendiri adalah aplikasi yang sangat membantu kita untuk mengorganisir berbagai macam kumpulan buku-buku yang kita upload,baik berupa dokumen, pdf, gambar dan lain lain. Di dalamiBooks kita bisa mendapatkan kemudahan membaca karena di dalamnya anda dapat mengkatagorikan file yang berupa pdf atau dokumen lainya dan $i B o o k s$ adalah aplikasi yang sangat baik dan terbaik bagi anda yang suka membaca banyak buku,karena dengan $i B o o k s$ anda bisa membaca ribuan buku bacaan anda tanpa harus membawa buku yang tebal dan banyak,dan ini lah aplikasi yang selalu di tampilkan apps store pada saat kita pertama kali membuat account apple id menurutM. Ilyas (2010).Namunapakah semua iBooks memenuhi standarisasi untuk pembelajaran iLearning.Ada beberapa komponen-komponen yang menentukan standarisasi sebuah iBooks. Hal tersebut 
menentukan mutu dan kualitas sebuah iBooks digunakan dalam proses pembelajaran berbasis iLearning didalam kelas.

\section{PERMASALAHAN}

Metode iLearning sedang marak-maraknya, persaingan di bidang pendidikan dalam menciptakan media pembelajaran semakin ketat.Pembelajaran berbasis iLearning yang memerlukan sebuah iBooks memerlukan standarisasi yang dapat menghasilkan good iBooks yang berkualitas yang memiliki komponen kokoh pada tahapan perancangan yang sistematis dan terencana. Sebuah perguruan tinggi akan tertarik dan mau menggunakan iLearningjika konsep yang digunakan menghasilkan tujuan yang sesuai standarisasi mutu pembelajaran yang di tetapkan. Media pembelajaran yang berupa iBooks memerlukan suatu standarisasi yang mencakup gambar, tabel, internal link, animasi, video, music, graphic, diagram, table of contents, link external dan lain sebagainya. Namum content yang ada pada iBooks sekarang belum mencapai standarisasi yang dapat menentukan apakah $i B o o k s$ tersebut dapat di gunakan sebagai media pembelajaran berbasis iLearning, seperti yang di gambarkan pada Gambar 1 .

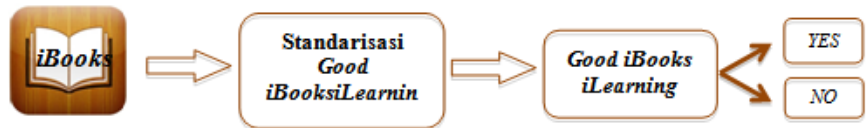

Gambar 1. Permasalahan Standarisasi GoodiBooks iLearning

Dari penjelasan di atas, dapat dirumuskan permasalahan yang ada adalah tidak adanya standarisasi $i$ Books yang bagus yang memenuhi kualitas dan kuantitas sebuah iBooks untuk mendukung iLearning. Dengan tidak adanya sebuah standarisasi iBooksakan terjadi beberapa dampak didalam pembelajaran. Dampak-dampak tersebut antara lain :

1. Dengan tidak terdapatnya soal didalam sebuah $i B o o k s$, dosen tidak dapat mengindikasi pencapaian kompetensi mahasiswa.

2. Dengan tidak terdapatnya table of content, mahasiswa yang menggunakan iBooksakan merasa kesulitan dalam mencari halaman pada setiap pertemuan di pembelajaran.

3. Mahasiswa akan mengalami kesulitan dalam memberikan hasil tugas yang mereka kerjakan dengan tidak adanya link yang menuju ke tautan tertentu. 


\section{LITERATUR REVIEW}

Dalam upaya perlu dilakukan studi pustaka sebagai salah satu dari penerapan metode penelitian yang akan dilakukan. Diantaranya adalah mengidentifikasikan kesenjangan (identify gaps), menghindari pembuatan ulang (reinventing the wheel), mengidentifikasikan metode yang pernah dilakukan, serta mengetahui orang lain yang spesialisasi dan area penelitian yang sama dibidang ini. Beberapa literature review tersebut adalah sebagai berikut :

1. Teknologi manajemen pengetahuan dan aplikasi, manajemen pengetahuan di survei menggunakan kajian literatur dan klasifikasi artikel tahun 1995-2002 untuk menjelajahi bagaimana teknologi KM dan aplikasi telah dikembangkan dalam periode ini.Berdasarkan ruang lingkup dari artikel 234 mengenai aplikasi dan manajemen pengetahuan, survei ini mengklasifikasikan teknologi KM menggunakan tujuh kategori sebagai: kerangka KM, sistem berbasis pengetahuan, data mining, teknologi informasi dan komunikasi, kecerdasan buatan atau sistem pakar, teknologi database, dan pemodelan. Mereka bersama-sama menggunakan aplikasi untuk penelitian yang berbeda dan masalah domain. Beberapa diskusi disajikan, menunjukkan perkembangan masa depan untuk teknologi manajemen pengetahuan dan aplikasi sebagai berikut: (1) Teknologi KM cenderung berkembang menuju orientasi pakar, dan aplikasi pengembangan teknologi KM adalah domain yang berorientasi. (2) Metodologi penelitian sosial yang berbeda, seperti metode statistik, disarankan untuk menerapkan pada teknologi KM sebagai jenis lain dari teknologi.(3) Integrasi metode kualitatif dan kuantitatif, dan integrasi penelitian teknologi KM dapat memperluas cakrawala kita tentang hal ini. (4) Kemampuan untuk terus menerus berubah dan mendapatkan pemahaman baru adalah kekuatan teknologi KM dan akan menjadi aplikasi karya masa depan.

2. Teachers'attitudes towards integration or inclusion. Berdasarkan asumsi bahwa keberhasilan pelaksanaan setiap kebijakan inklusif sangat tergantung pada pendidik yang bersikap positif tentang hal itu, banyak penelitian telah berusaha untuk memeriksa pendekatan sikap pengajar terhadap integrasi dan baru-baru ini, masuknya anak-anak dengan kebutuhan pendidikan khusus di sekolah mainstream. Tulisan ini membahas badan besar penelitian dan dalam melakukannya, mengeksplorasi sejumlah faktor yang mungkin berdampak pada penerimaan guru dengan prinsip inklusi. Analisis ini menunjukkan bukti sikap positif, tetapi tidak ada bukti penerimaan inklusi total atau pendekatan 
untuk menyediakan pendidikan khusus. Sikap guru ditemukan sangat dipengaruhi oleh sifat dan keparahan kondisi yang disajikan kepada mereka (anak atau variabel terkait) dan kurang oleh variabel guru-terkait. Selanjutnya, lingkungan yang berhubungan dengan variabel pendidikan, seperti ketersediaan dukungan fisik dan manusia, secara konsisten ditemukan terkait dengan sikap terhadap inklusi. Setelah diskusi singkat tentang isu-isu metodologis sangat penting untuk melakukan penelitian, memberikan arah untuk penelitian masa depan berdasarkan metodologi alternatif.

3. Literatur Review dalam Permainan dan Pembelajaran, John Kirriemuir 1, Angela McFarlane 2 (2004). Tinjauan ini dimaksudkan sebagai pengantar yang tepat terhadap pemikiran terkini tentang peran permainan komputer dalam mendukung anak-anak dalam belajar dan keluar dari sekolah. Menyoroti bidang utama di lapangan pada penelitian ini, khususnya meningkatnya minat dalam belajar yang menyenangkan, pembelajaran melalui kolaborasi permainan tampaknya dapat meningkatkan minat dalam belajar. Pada saat yang sama, meninjau dan mengambil nada yang diukur dalam melihat beberapa kendala dan tantangan untuk menggunakan permainan dalam sistem pendidikan kita saat ini menjadi model pembelajaran yang menyenangkan.

4. Penelitian yang dilakukan oleh Glenn Fleishman, "The best iPhone and iPad apps for work and play". Ditetapkan untuk mengetahui cara menggunakan perangkat anda dalam menemukan film, membaca buku, mengambil file dengan jarak jauh, membuat panggilan telepon, memainkan permainan atau strategi untuk mencapai host yang berguna, dan kadang-kadang melakukan tugas yang benar-benar tidak berguna. Glenn menyaring dan menguji ribuan aplikasi untuk menemukan hampir 200 program yang memenuhi kriteria-nya. Menarik, menghibur, berguna dan aplikasi yang memiliki lika bintang. Pilihannya yang jelas berguna akan mengejutkan anda dan membantu anda menyelesaikan tugas-tugas, bersenang-senang, menjadi kreatif, dan belajar sesuatu yang baru. apakah anda memerlukan aplikasi untuk melacak status pengiriman paket atau mengubah perangkat anda menjadi pembaca barcode? Mulai membaca dan pemindaian. Ingin menonton film terbaik dari studio atau ciptaan anda sendiri. Semua itu dapat diarahkan ke aplikasi yang sempurna. Aplikasi yang dapat memainkan musik sangat penting, membuat anda lebih produktif,dapat melacak file, dan masih banyak lagi.

5. Penelitian yang dilakukan oleh Joe Lennon Software developer berjudul "Create modern Web sites using HTML5 and CSS3". Penelitian ini menjelaskan bahwa pada bagian ini, kita menemukan beberapa fitur baru menggunakan HTML5. Pertama kali anda akan belajar tentang unsur-unsur 
semantik baru yang bertujuan untuk memberi makna tentang berbagai bagian halaman Web modern seperti: sisi header, footer, bar navigasi, bar, dan sebagainya. Berikutnya, anda akan belajar tentang elemen baru <canvas> yang penting dan gambar 2D API JavaScript yang dapat anda gunakan untuk membuat bentuk, teks, animasi, transisi, dan banyak lagi. Setelah ini, kita akan melihat bagaimana < audio $>$ baru dan elemen $<$ video $>$ yang bermaksud untuk mengganti ketergantungan pada saat ini. Web pada Flash sebagai platform multimedia. Selanjutnya, kita akan diperkenalkan oleh API sebagai penyimpanan lokal dan offline. Aplikasi yang akan datang menjadi aplikasi Web yang sesuai dengan kebutuhan desktop mereka dalam hal fungsi, bahkan ketika tidak terhubung ke jaringan atau Internet. Bagian ini dibungkus dengan gambaran singkat tentang elemen-elemen baru lainnya, atribut, dan API yang diusulkan dalam spesifikasi HTML5 saat ini.

6. Penelitian ini dilakukan oleh Gene Backlin dari tahun 2010 berjudul "Professional iPhone and iPad Application Development". Penelitian ini dilakukan atas dasar kebutuhan dalam membuat aplikasi top-notch untuk iPhone dan iPad developers yang menuntut panduan lanjutan untuk menggunakan versi paling terakhir dari iPhone dan iPad SDK untuk mengembangkan aplikasi, dan buku ini menjawab hal tersebut. Dilengkapi lebih dari dua puluh aplikasi yang lengkap dan dirancang untuk menciptakan kembali, membangun kembali, dan digunakan kembali oleh pengembang profesional. Sumber ini menggali dengan mengacu pada kehidupan dunia yang semakin populer, dengan pengembangan aplikasi dan menyajikan panduan langkah demi langkah untuk membuat aplikasi yang superior untuk $i$ Phone dan iPad. Mengembangkan banyak alat dan belajar bagaimana menggunakannya. Dengan cakupan versi terbaru dari iPhone dan $i P a d S D K$, dan jumlah aplikasi mandiri, buku ini akan menjadi luar biasa untuk referensi di masa depan. Dari pembuatan back cover, membangun, dan menggunakan kembali aplikasi dengan $i$ Phone $S D K$. Pengembang sedang mencari sumber canggih yang membawa mereka untuk melalui apa yang sekarang menjadi pasar untuk $i P h o n e$ dan $i P a d$ yang memenuhi permintaan tersebut. Profesional iPhone dan iPad.

7. Penelitian ini dilakukan oleh Dr. Rory Lewis berjudul "iPhone and iPad Apps for Absolute Beginners" tahun 2010. Penelitian ini membahas tentang bagaimana anda membangun sebuah aplikasi untuk iPhone dan $i P a d$ ? Apakah anda perlu menghabiskan bertahun-tahun untuk belajar bahasa pemrograman yang rumit? Bagaimana Objective-C, Kakao Touch, dan SDK? Jawabannya adalah bahwa anda tidak perlu mengetahui hal-hal itu. Siapa saja bisa mulai 
membangun aplikasi sederhana untuk $i P h o n e$ dan $i P a d$, dan buku ini akan menunjukkan kepada anda bagaimana caranya.

8. Penelitian ini dilakukan oleh Chris Apers dan Daniel Paterson berjudul "Beginning iPhone and iPad Web Apps: Scripting with HTML5, CSS3, and JavaScript". Penelitian ini membahas mengenai pengembangan aplikasi $i$ Phone dan profesional web yang bekerja keras dalam pengenalan iPad, kita mungkin akan merasa tertinggal jauh. Kita tidak perlu bekerja keras melalui Objective-C, Kakao Touch, Apple API Cocoa. WebKit dengan dukungan HTML5, yang berarti bahwa setiap web developer yang berkeinginan untuk bergabung pada gelombang kedua mobile App Apple dan membuat aplikasi menarik yang membahas fitur unik baik dari $i$ Phone maupun $i P a d$. Pada awalnya iPhone dan iPad Web Apps: Scripting dengan HTML5, CSS3, dan JavaScript membawa kita melalui setiap aspek terakhir Mobile Web Standard serta fitur khusus dari iPhone dan $i P a d$. Kita akan melampaui Web 2.0 dan Ajax untuk belajar tentang WebKit dan Mobile Safari, HTML5 dan CSS3, Vector Graphics dan dukungan multimedia. Kita akan menemukan apa yang menjadi kebutuhana fitur hardware iPhone dan $i P a d$. Kita juga dapat mengambil keuntungan dari kemampuan perangkat khusus tersebut. Pasar untuk aplikasi web adalah memperluas dan mengkombinasikan dari $i$ Phone dan $i P a d$ yang kompetitif. Apa yang anda pelajari dalam mengambil kemampuan yang ada pada web dan menyebarkannya di iPad dan iPhone dengan dasar desain kedua layar $i P h o n e$ kecil dan layar besar $i P a d$. Kunci untuk pengembangan aplikasi web yang dibangun ke HTML5, WebKit, dan Mobile Safari. Untuk mendukung mobile media dengan $i P h o n e$ dan fitur khusus $i P a d$. Bagaimana cara untuk mengambil keuntungan dari fitur-fitur canggih untuk grafis CSS3. Alamat antar muka layar sentuh Apple dan berinteraksi dengan sentuhan API Cocoa .

9. Literasi di Era Teknologi, oleh Riel tahun 2000. Tujuan pendidikan yang terkait dengan lingkungan belajar sebagai salah satu perubahan. Tujuan keaksaraan 100 tahun yang lalu bagi banyak siswa itu harus mampu membaca dan menulis nama, menyalin dan membaca teks dan menghasilkan daftar barang dagangan. Melihat tujuan saat ini yang membutuhkan penguasaan atas berbagai genre menulis: persuasif,ekspresif,ekspositoris, prosedural dan mengharapkan siswa untuk dapat menafsirkan, membandingkan, kontras, dan menganalisis teks kompleks.

10. Pembelajaran dengan Bantuan Komputer, Sistem Belajar Terpadu, dan Hasil yang Baik untuk Literasi dan Berhitung Secara keseluruhan. Efektivitas belajar 
yang dibantu komputer (CAL) pada saat ini belum meyakinkan. Untuk saat ini, telah terbukti kurang efektif dari intervensi dalam pendidikan. Dalam mempertimbangkan hasil penelitian evaluatif dalam belajar dengan bantuan komputer,kita harus menghindari media perancu dengan metode ini.Umumnya, komputer dibantu perangkat lunak untu pembelajaran yang menggunakan teori, salah satu yang telah mengungsi di dalam kelas terlihat menjadi konstruktivis sosial dalam pembelajaran. Khususnya di kelas utama Selandia Baru, pendekatan dari perangkat lunak mungkin berbeda jauh dari kelas pedagogi yang diterima secara luas. Bantuan program komputer dalam pembelajaran, sistem pembelajaran terutama yang terintegrasi, umumnya mahal. Keberhasilan mereka dan efektivitas biaya program relatif terhadap alternatif, khususnya yang berkaitan dengan membaca, patut dipertanyakan. Sementara penelitian komparatif berkenaan dengan efektivitas, penelitian komparatif yang baik dalam kaitannya dengan efektivitas biaya yang kurang.

Dari beberapa Literature Review diatas banyak peneliti yang melakukan penelitian seperti teknologi manajemen pengetahuan dan aplikasi, aplikasi iPhone dan $i P a d$ dan lain sebagainya. Namun belum adanya penelitian yang menerangkan secara gamblang tentang standarisasi goodiBooks untuk pembelajaran iLearning.

\section{PEMECAHAN MASALAH}

Untuk mengatasi permasalahan yang dijabarkan di atas, maka diperlukan suatu bagan standarisasi iBooks yang meliputi soal, quiz, tutorial, gambar, tabel, internal link, animasi, video, music, graphic, kesimpulan di setiap pertemuan, syllabus, PO, diagram, table of contents, photo, formula atau rumus, algoritma, link to email dan link external. Saat ini penerapan standarisasi sebuah iBooks belum mencapai seluruh elemen atau content dalam perancangan sebuah goodiBooks. Alhasil suatu tahapan dalam menciptakan iBooks yang berstandar iLearning menjadi sebuah hal pokok dalam pembuatan goodiBooks.

Penggunaan media iBooks adalah sesuatu yang baru dalam pembelajaran berbasis iLearning. Maka dari itu penjabaran pada tiap-tiap content harus sesuai dengan standarisasi yang semestinya yang dibutuhkan dalam proses pembelajaran berbasis iLearning. Dikarenakan belum adanya panduan standarisasi goodiBooksiLearning yang dibutuhkan maka dari itu dimulai suatuperancangan tahapan pembuatan iBooks berstandar iLearning.Adapun yang dimaksud dengan Standarisasi goodiBooksiLearning adalah terdapat 20 cheklist komponen iBooks 
yang menyatakan bahwa iBooks tersebut layak dan mencapai standarisasi untuk menjadi media pembelajaran berbasis iLearning.

Standarisasi merupakan penentuan ukuran yang harus diikuti dalam memproduksikan sesuatu, sedang pembuatan banyaknya macam ukuran barang yang akan diproduksikan merupakan usaha simplifikasi. Istilah standarisasi berasal dari kata standar yang berarti satuan ukuran yang dipergunakan sebagai dasar pembanding kuantita, kualitas, nilai, hasil karya yang ada. Dalam arti yang lebih luas maka standar meliputi spesifikasi baik produk, bahan maupun proses. Untuk spesifikasi adalah batasan minimum dan atau maksimum dari pada sifat-sifat tertentu dengan menggunakan metode tertentu. Berkaitan dengan spesifikasi yang memenuhi standarisasi sebuah iBooks iLearning, diilustrasikan pada tabel dan gambar berikut:

Tabel 1. Spesifikasi Komponen iBooks iLearning

\begin{tabular}{|c|l|l|}
\hline No & \multicolumn{1}{|c|}{ Spesifikasi } & \multicolumn{1}{c|}{ Fungsi } \\
\hline 1. & Soal & Memudahkan mahasiswa mencari kumpulan soal \\
\hline 2. & Quiz & Melatih mahasiswa dalam pembelajaran \\
\hline 3. & Tutorial & Memberikan pembelajaran dalam bentuk video \\
\hline 4. & Gambar & Memberi kesan kreatif, imaginatif, artistik \\
\hline 5. & Tabel & Berisi tabel - tabel dalam materi perkuliahan \\
\hline 6. & Internal link & Link yang menuju halaman lain didalam iBook \\
\hline 7. & Animasi & Memberi kesan bergerak dalam iBook \\
\hline 8. & Video & Memuat video-video di dalamiBook \\
\hline 9. & Music & Memuat music-music didalamiBook \\
\hline 10. & Graphic & Berisi grafik dalam materi perkuliahan \\
\hline 11. & Kesimpulan & Kesimpulan pada setian pertemuan \\
\hline 12. & Syllabus & Berisi silabus mata kuliahiBook tersebut \\
\hline 13. & PO & Penilaian Objektif untuk mata kuliah \\
\hline 14. & Diagram & Berisi diagram dalam materi perkuliahan \\
\hline 15. & Table of Contents & Berisi Daftar isi dalam sebuah iBook \\
\hline 16. & Photo & Memberi kesal visualisasi \\
\hline 17. & Formula atau rumus & Berisi rumus-rumus dalam materi perkuliahan \\
\hline 18. & Algoritma & Berisi algoritma dalam materi perkuliahan \\
\hline 19. & Link to email & Link yang menuju ke email dosen pengajar \\
\hline 20. & Link external & Link yang menuju ke situs-situs tertentu \\
\hline & & \\
\hline
\end{tabular}

Tampak pada tabel 1. Spesifikasi komponen iBooks iLearning terdapat 20 komponen yang menjadi pendukung pembelajaran iLearning. 


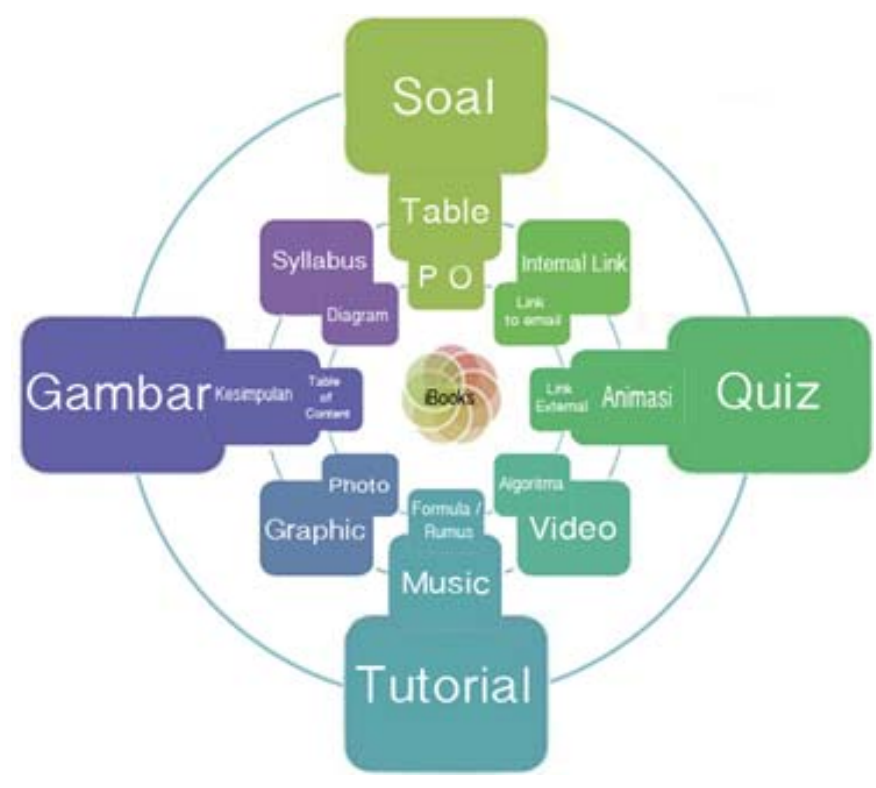

Gambar 2. iLearning Architecture

Tampak pada Gambar 2 diatas, menjelaskan Arsitektur iLearning yang menjabarkan 20 komponen yang saling mendukung dan berkaitan untuk membentuk $i B o o k s$ yang berkualitas. Secara umum definisi dan fungsi dari masing-masing komponen diatas adalah sebagai berikut :

\section{Soal}

Soal adalah sebagai indikator atau indikasi pencapaian kompetensi yang menggunakan kata kerja operasional yang dapat diukur dan mengacu pada materi pembelajaran sesuai kompetensi.Soal disesuaikan dengan kebutuhan indikator dosen dalam menilai pemahaman mahasiswa dalam materi pembelajaran yang disampaikan.

2. Quiz

Quiz adalah merupakan ujian lisan atau tertulis yang singkat. Bisa juga dikatakan perlombaan adu cepat menjawab pertanyaan dengan cepat tepat dan cerdas cermat. (Gambar 3) 


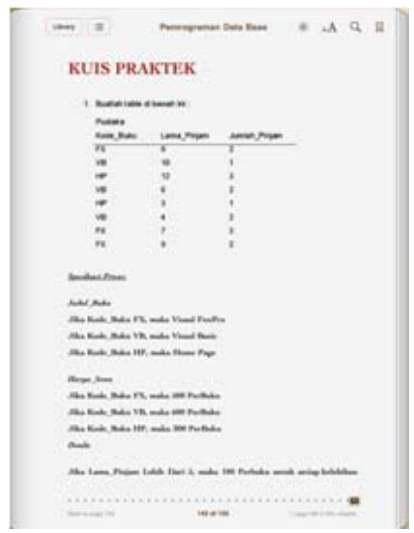

Gambar 3. Contoh Kuis pada iBooks

\section{Tutorial}

Tutorial adalah pembimbingan kelas oleh seorang pengajar (tutor) untuk seorang mahasiswa atau sekelompok kecil mahasiswa dan bisa dikatakan pengajaran tambahan melalui tutor.Tutorial disini dapat berupa tahapan yang telah berupa video ataupun berupa tahapan materi dengan format epub. (Gambar 4)

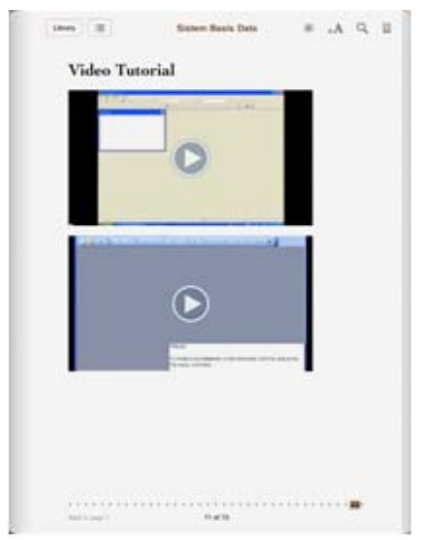

Gambar 4. Contoh Tutorial pada iBooks

\section{Gambar}

Gambar adalah tiruan visual (orang, binatang, tumbuhan, benda dan lain-lain) yang dibuat dengan coretan pensil dan sebagainya pada kertas dan sebagainya; lukisan. 


\section{Tabel}

Tabel adalah daftar berisi ikhtisar sejumlah (besar) data informasi, biasanya berupa kata-kata dan bilangan yang tersusun secara bersistem, urut ke bawah dengan lajur dan deret tertentu dengan garis pembatas sehingga dapat dengan mudah disimak. (Gambar 5)

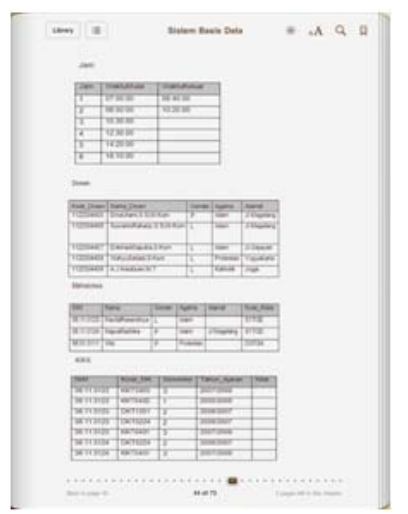

Gambar 5. Contoh Tabel pada iBooks

\section{Internal Link}

Internal Link adalah tautan yang sengaja dibuat oleh admin atau pemilik iBooks. Tautan tersebut adalah tautan antar halaman yang saling berkaitan atau internal linking ini bisa dikatakan sebagai related post secara manual karena related post yang biasa berada pada tiap blog adalah dilakukan secara otomatis dan menggunakan javascript. (Gambar 6)

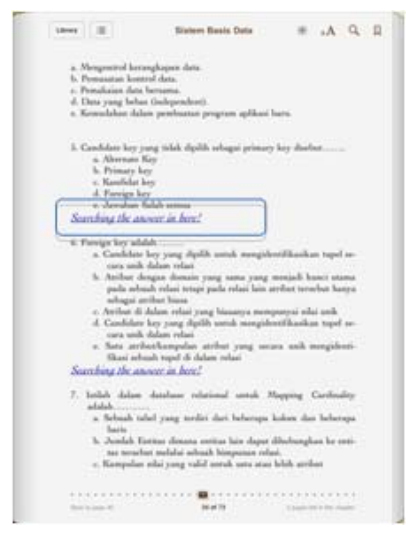

Gambar 6. Contoh Internal Link pada iBooks 


\section{Animasi}

Animasi adalah berbentuk rangkaian lukisan atau gambar yang digerakkan secara mekanik elektronis sehingga tampak di layar menjadi bergerak.

\section{Video}

Video adalah teknologi untuk menangkap, merekam, memproses, mentransmisikan dan menata ulang gambar bergerak.Biasanya menggunakan film seluloid, sinyal elektronik, atau media digital.Video juga bisa dikatakan sebagai gabungan gambar-gambar mati yang dibaca berurutan dalam suatu waktu dengan kecepatan tertentu. Gambar-gambar yang digabung tersebut dinamakan frame dan kecepatan pembacaan gambar disebut dengan frame rate, dengan satuan fps (frameper second). Karena dimainkan dalam kecepatan yang tinggi maka tercipta ilusi gerak yang halus, semakin besar nilai frame rate maka akan semakin halus pergerakan yang ditampilkan.

9. Music

Music adalah bunyi yang diterima oleh individu dan berbeda-beda berdasarkan sejarah, lokasi, budaya dan selera seseorang. Definisi sejati tentang musik juga bermacam-macam, antara lain:

- Segala bunyi yang dihasilkan secara sengaja oleh seseorang atau kumpulan dan disajikan sebagai music.

10. Graphic

Graphic adalah merupakan visualisasi table.Table yang berupa angka angka dapat disajikan atau ditampilkan ke dalam bentuk gambar. Jenis grafik, ada beberapa macam grafik diantaranya adalah :

1. Grafik batang (histogram) merupakan dipakai untuk menekankan perbedaan tingkat nilai dan beberapa aspek, contohnya grafik penyesuaian barang.

2. Grafik garis merupakan dipakai untuk menggambarkan perkembangan atau perubahan dari waktu ke waktu, contohnya grafik kesehatan anak.

3. Peta dan Denah

Peta adalah penyajian visual tentang suatu wilayah dalam bentuk gambar. Denah adalah penyajian visual suatu tempat atau ruangan dalam bentuk gambar.

\section{Kesimpulan}

Kesimpulan berasal dari fakta-fakta atau hubungan yang logis.Pada umumnya kesimpulan terdiri atas kesimpulan utama dan kesimpulan 
tambahan.Kesimpulan utama adalah yang berhubungan langsung dengan permasalahan.Dengan demikian, kesimpulan utama harus bertalian dengan pokok permasalahan dan dilengkapi oleh bukti-bukti.Pada kesimpulan tambahan, penulis tidak mengaitkan pada kesimpulan utama, tetapi tetap menunjukkan fakta-fakta yang mendasarinya.Dengan sendirinya, penulis tidak dibenarkan menarik kesimpulan yang merupakan hal-hal baru, lebih-lebih jika dilakukan pada kesimpulan utama.Jika penulis bermaksud menyertakan data atau informasi baru maka hendaknya dikonsentrasikan pada bab-bab uraian dan bukannya pada kesimpulan.Pendek kata, kesimpulan adalah berisi pembahasan tentang kesimpulan semata.

\section{Syllabus}

Syllabus adalah rencana pembelajaran pada suatu atau kelompok mata pelajaranatautema tertentu yang mencakup standar kompetensi , kompetensi dasar, materi pokokataupembelajaran, kegiatan pembelajaran, indikator pencapaian kompetensi untuk penilaian, penilaian, alokasi waktu, dan sumber belajar. (Gambar 7)

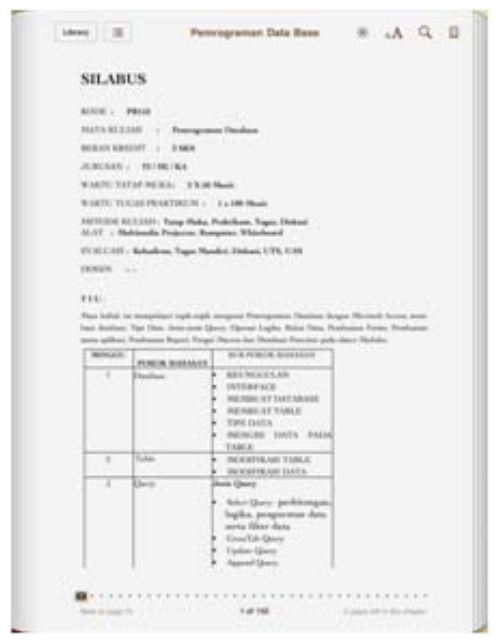

Gambar 7. Contoh Silabus pada iBooks

\section{Penilaian Objektif}

Penilaian Objektif adalah penilaian yang dibuat berasaskan pertimbangan terhadap bukti empirikal.Bukti empirikal pencapaian biasanya diperoleh secara pengukuhan terhadap penguasaan pelajar dengan menggunakan alat ukur yang dinamakan ujian.(Gambar 8) 


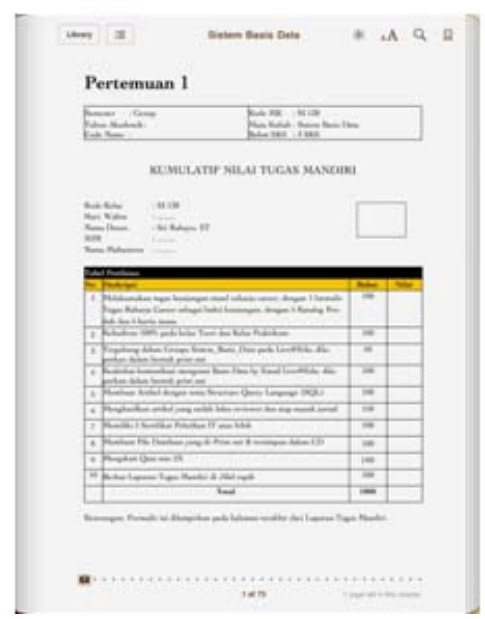

Gambar 8. Contoh Penilaian Objektif pada iBooks

\section{Diagram}

Diagram adalah gambaran (buram, sketsa) untuk memperlihatkan atau menerangkan sesuatu.

\section{Table of Content}

Table of Content adalah daftar isi atau list atau index seluruh tulisan yang ada di makna kata.Index disesuaikan dengan kategori tulisan. (Gambar 9)

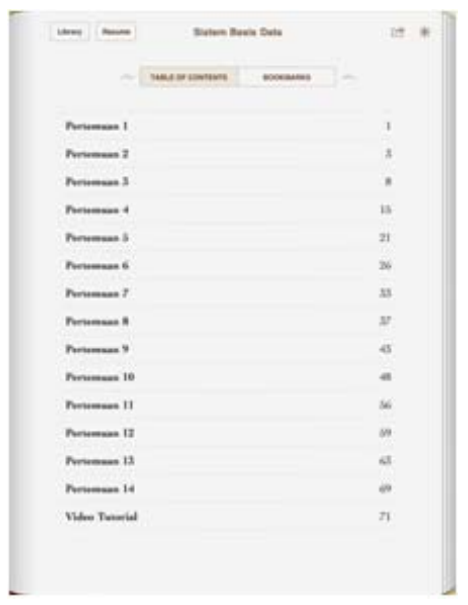

Gambar 9. Contoh Table of Content pada iBooks 
Photo yaitu gambar yang dihasilkan dengan menangkap cahaya pada medium yang telah dilapisi bahan kimia peka cahaya atau sensor digital (kombinasi dari photo yang berarti cahaya, dan graph yang berarti catatan, tulisan, atau lukisan).

\section{Formula atau Rumus}

Formula atau Rumus adalah ringkasan (hukum, patokan, dan sebagainyadalam ilmu kimia, matematika, dan sebagainya) yang dilambangkan oleh huruf, angka, atau tanda: - kimia untuk air ialah $H 2 O ; 2$ pernyataan atau simpulan asas, pendirian, ketetapan, dan sebagainya yang disebutkan dengan kalimat yang ringkas dan tepat.

\section{Algoritma}

Algoritma adalah urutan langkah-langkah logis penyelesaian masalah yang disusun secara sistematis dan logis.Kata logis merupakan kata kunci dalam algoritma.Langkah-langkah dalam algoritmaharus logis dan harus dapat ditentukan bernilai salah atau benar.

\section{Link to Email}

Link to Email adalah sebuah acuan dalam dokumen hiperteks (hypertext) ke sebuah email tertentu. (Gambar 10)

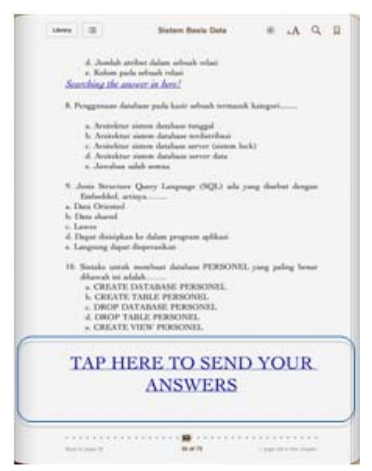

Gambar 10. Contoh Link to Email pada iBooks

\section{Link External}

Link External adalah tautan yang sengaja dibuat oleh admin atau pemilik iBook. Tautan tersebut adalah mengarah pada sebuah alamat atau situs situs tertentu seperti www.google.com, www.facebook.com, dan lain sebagainya. Mengacu pada 20 komponen yang menjadi standarisasi sebuah iBooks iLearning, ada sebuah formulir standarisasi yang berfungsi untuk mengetahui apakah $i B o o k s$ tersebut sudah berstandar iLearning atau belum. Berikut ini adalah formulir standarisasi iBooks iLearning (Tabel 2). 
Tabel 2. Formulir Standarisasi iBooks iLearning

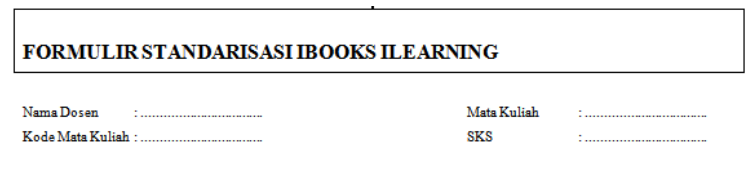

\begin{tabular}{|c|c|c|c|}
\hline NO & COMPONENT & \multicolumn{2}{|c|}{ KETERANGAN } \\
\hline \hline 1 & Soal & $\square$ Yes & $\square$ No \\
\hline 2 & Quiz & $\square$ Yes & $\square$ No \\
\hline 3 & Tutorial & $\square$ Yes & $\square$ No \\
\hline 4 & Gambar & $\square$ Yes & $\square$ No \\
\hline 5 & Tabel & $\square$ Yes & $\square$ No \\
\hline 6 & Internal link & $\square$ Yes & $\square$ No \\
\hline 7 & Animasi & $\square$ Yes & $\square$ No \\
\hline 8 & Video & $\square$ Yes & $\square$ No \\
\hline 9 & Music & $\square$ Yes & $\square$ No \\
\hline 10 & Graphic & $\square$ Yes & $\square$ No \\
\hline 11 & Kesimpulan & $\square$ Yes & $\square$ No \\
\hline 12 & Syllabus & $\square$ Yes & $\square$ No \\
\hline 13 & PO & $\square$ Yes & $\square$ No \\
\hline 14 & Diagram & $\square$ Yes & $\square$ No \\
\hline 15 & Table of Contents & $\square$ Yes & $\square$ No \\
\hline 16 & Photo & $\square$ Yes & $\square$ No \\
\hline 17 & Formula atau rumus & $\square$ Yes & $\square$ No \\
\hline 18 & Algoritma & $\square$ Yes & $\square$ No \\
\hline 19 & Link to email & $\square$ Yes & $\square$ No \\
\hline 20 & Link external & $\square$ Yes & $\square$ No \\
\hline \hline & HASIL & $\square$ Layak & $\square$ Tidak Layak \\
\hline
\end{tabular}

\section{LISTING PROGRAM}

Dalam pembuatan iBooksterdapat metode dengan menggunakan coding, metode coding ini merupakan metode yang mengimplementasikan beberapa materi pembelajaran kedalam file $e P u b$. Berikut merupakan salah satu contoh coding dalam pembuatan iBooksiLearning:

$<$ ?xml version="1.0" encoding="UTF-8" ?>

<!DOCTYPE html PUBLIC “-//W3C//DTD XHTML 1.1//EN” "http:// www.w3.org/TR/xhtml11/DTD/xhtml11.dtd">

$<$ html xmlns="http://www.w3.org/1999/xhtml" xml:lang="en">

$<$ head $>$

$<$ meta http-equiv="Content-Type" content="application/xhtml+xml;

charset=utf- $8 ">$

$<$ title $>$ Pride and Prejudice $</$ title $>$ 
$<$ link rel="stylesheet" href="css/main.css" type="text/css"/>

$<$ head $>$

$<$ body $>$

$</$ body $>$

$</$ html $>$

\section{IMPLEMENTASI}

Pembelajaran berbasis iLearning telah di implementasikan pada Perguruan Tinggi dengan menggunakan media iBooks sebagai bahan ajar dalam perkuliahan.Dengan menggunakan media $i B o o k s$ sebagai acuan dalam pembelajaran di butuhkan audio visualisasi yang menarik bagi mahasiswa.Berikut ini adalah tampilan video (Gambar 11) dan tampilan music (Gambar 12) di dalam iBooks.

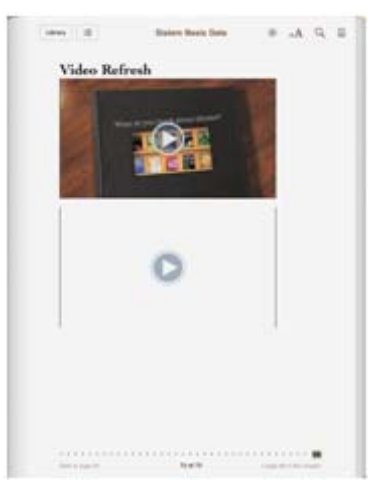

Gambar 11. Contoh Video pada iBooks

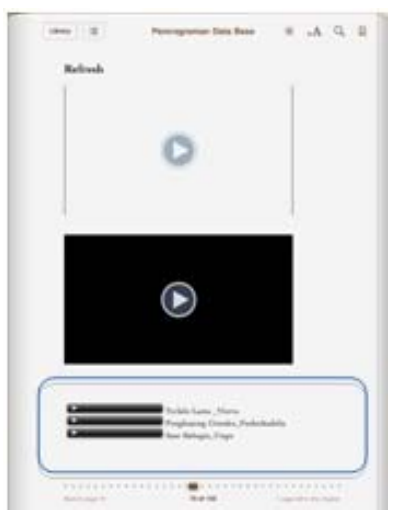

Gambar 12. Contoh Music pada iBooks 
Dari uraian 20 komponen-komponen iBooksiLearning di atas disimpulkan bahwa terdapat 6 kelebihan dan 3 kekurangan dengan adanya standarisasi iBooksiLearning tersebut. Antara lain sebagai berikut:

\section{KELEBIHAN STANDARISASI $\boldsymbol{i B O O K S}$ iLEARNING}

Kelebihan dalam standarisasi $i B o o k s$ dalam menunjang pembelajaran iLearning adalah dapat menghantarkan metode pembelajaran iLearning menjadi bermutu dan berbobot. Disamping itu masih banyak kelebihan yang didapat dalam penelitian iBooks untuk standarisasi materi iLearning, diantaranya adalah:

1. Kelebihan dari Standarisasi iBooksiLearning adalah dapat menjadikan sebuah media pembelajaran yang mempunyai kualitas sempurna.

2. Dapat menyesuaikan dengan perkembangan kemajuan fasilitas teknologi komputerisasi yang ada.

3. Dilihat dari sudut efektifitas media iBooks yang dihasilkan lebih menarik, lebih banyak memberikan kesan dan lebih efektif.

4. Melatih pelajar lebih mandiri dalam pembelajaran.

5. Menghemat biaya pendidikan secara keseluruhan baik dalam segi infrastruktur, buku, alat tulis, kertas dan sebagainya.

6. Mampu meningkatkan kemampuan belajar dilihat dari segi visual pelajar jadi mudah mengerti dan cepat untuk menghafal.

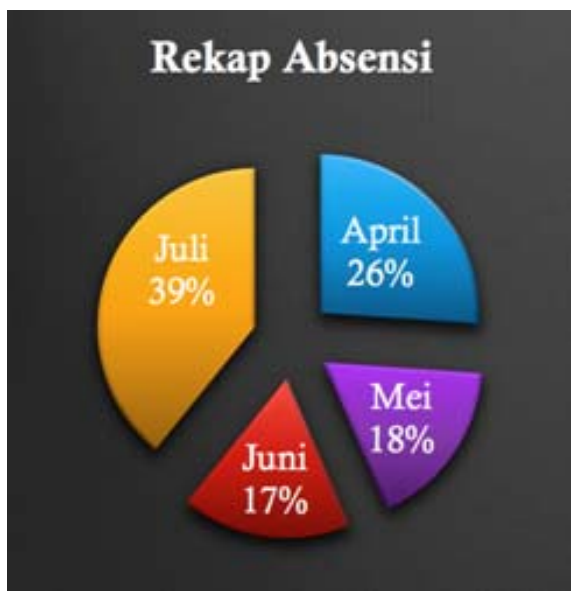

Gambar 13. Grafik Peningkatan Absensi Mahasiswa 
Tampak pada Gambar 13 di atas, Grafik peningkatan absensi mahasiswa menunjukan bahwa metode iLearning mampu meningkatkan semangat belajar para mahasiswa.

\section{KEKURANGAN STANDARISASI $\boldsymbol{i B O O K S ~}$ iLEARNING}

Disamping kelebihan yang ada, iLearning ini juga mempunyai 3 kekurangan diantaranya adalah sebagai berikut:

1. Konsep iLearningini tidak dapat diikuti kalangan yang tidak menguasai atau tidak memiliki fasilitas yang dibutuhkan dalam pembuatan $i B o o k s$ itu sendiri.

2. Tidak semua point yangada pada Standarisasi GoodiBooks mendukung pembelajaran materi pada mata kuliah iLearning seperi mata kuliah Pancasila tidak banyak memerlukan contentalgoritma pada materi pembelajarannya.

3. Konsep penelitian iLearning with goodiBooks ini masih dalam tahap level I pengembangan. Jadi diharapkan untuk kedepannya banyak memerlukan penyempurnaan pada tahapan berikutnya.

\section{KESIMPULAN}

iLearning merupakan metode yang mengintegrasikan sumber daya dalam menjalankan Tridarma Perguruan Tinggi dengan menggunakan $i P a d$ menurut Untung Rahardja (2011).Maka dari itu dalam menjalankan metode iLearning di butuhkan sebuah aplikasi yang mendukung berjalannya metode tersebut.iBooks adalah salah satu aplikasi yang mendukung iLearning, definisi dari iBooks sendiri adalah aplikasi yang sangat membantu kita untuk mengorganisir berbagai macam kumpulan buku buku yang kita upload,baik berupa dokumen,pdf, gambar dan lain lain. Di dalamiBooks kita bisa mendapatkan kemudahan membaca karena di dalamnya anda dapat mengkatagorikan file yang berupa pdf atau dokumen lainya dan $i B o o k s$ adalah aplikasi yang sangat baik dan terbaik bagi anda yang suka membaca banyak buku,karena dengan $i$ Books anda bisa membaca ribuan buku bacaan anda tanpa harus membawa buku yang tebal dan banyak,dan ini lah aplikasi yang selalu di tampilkan apps store pada saat kita pertama kali membuat account apple id menurutM. Ilyas (2010). User dapat dengan mudah mengunduh buku yang diinginkan, ada beberapa pilihan buku, ada yang free dan tentu saja ada yang berbayar.Standarisasi dalam pembuatan iBooks sangat dibutuhkan dalam perancangan media pembelajaran berbasis iLearning. Spesifikasi yang ada di dalam iBooks sangat mempengaruhi berjalannya sebuah kegiatan belajar mengajar berbasis iLearning.Dengan adanya standarisasi pembuatan iBooks yang memenuhi pembelajaran iLearning ini media pembelajaran yang dihasilkan menjadi suatu hal yang berkualitas dan institusi yang mengembangkan nantinya diharapkan menjadi institusi yang unggulan. 


\section{DAFTAR PUSTAKA}

1. Adi, A. (2009). Model Pembelajaran Cooperative Integrated Reading and Composition (CIRC).[Online].Tersedia:http://adyajuz.blogspot.com/ 2009/03/modelpembelajaran-cooperative.html [accessed 17/10/2011].

2. Arikunto, S. (2006). Prosedur Penelitian. Jakarta: Rineka Cipta.

3. Backlin, Gene (2010). Professional iPhone and iPad Application Development. http://www.amazon.com/Professional-iPhone-ApplicationDevelopment-Programmer/dp/0470878193 [accessed 20/10/2010].

4. Bisri,A. M. (2008). Sekitar Pembelajaran Efektif. Tersedia di alamat: http:/ /pendis.depag.go.id/madrasah/Insidex.php?i_367=at02100015. [accessed 17/10/2011].

5. Gilliam dan Dixon, Hazel.(1991). Integrating Learning Planned Curriculum Units. Auastralia: Bookshelt Publishing Australia.

6. Lie, A. (2004). Cooperative Learning: Mempraktikkan Cooperative Learning di Ruang-ruang Kelas. Jakarta: Grasindo

7. Maimunah (2010).Journal CCIT Vol.3 No.2. Tangerang: Raharja Enrichment Centre (REC).

8. Mulyono,A.(2000). Kamus Besar Bahasa Indonesia. Jakarta: Balai Pustaka

9. NIE, Singapore, General Typology of Teaching Strategies in Integrated Learning System. http://www.microlessons.com [accessed 19/10/2010].

10. Prabowo, (2000). Pembelajaran Terpadu. Tersedia di alamat : http:// anwarholil.blogspot.com/2008/04/pengertian-pembelajaran-terpadu.html [accessed 20/10/2011].

11. Slavin, R.E. (2005). Coopretative Learning, Teori, Riset, Dan Praktik. Bandung : Nusa Media

12. Trianto. (2007). Model Pembelajaran Terpadu dalam Teori dan Praktek. Jakarta: Prestasi Pustaka. 